\title{
The Potential Protective Role of Vitamin $E$ and Selenium against Sub-chronic Toxicity of Hexavalent Chromium on the Testis of Adult Male Albino Rats
}

\author{
Amira Abd- El Raouf Mohammed ${ }^{1}$ and Wesam Abd-Elsalam Abd-Elwahab ${ }^{2}$ \\ ${ }^{1}$ Cell Biology Department,National Research Center, Dokki. \\ ${ }^{2}$ Forensic Medicine and Clinical Toxicology Department Faculty of Medicine for Girls Al-Azhar University. \\ Cairo, Egypt.
}

\begin{abstract}
Introduction Uptake of Hexavalent chromium (Cr 6) by the testis and its subsequent reduction to trivalent chromium is well known. Several studies attributed $\mathrm{Cr} 6$ testicular toxicity to oxidative stress. Vitamin $\mathrm{E}$ is a lipid soluble antioxidant prevents damage to membranes. Selenium (Se) is an essential micronutrient with an antioxidant activity. This study aimed to investigate the potential protective role of vitamin $\mathrm{E}$ and selenium against sub-chronic toxicity of $\mathrm{Cr} 6$ on testes of adult male albino rats through biochemical, cytogenetic and sperm analysis. Methodology: The duration of the present study was six weeks and was carried out on 60 adult male albino rats. They were divided into 10 rats of six groups, control group, selenium group $(0.5 \mathrm{mg} / \mathrm{kg}$ by oral gavage), vitamin E group (125 $\mathrm{mg} / \mathrm{kg}$ by oral gavage), $\mathrm{Cr} 6$ group $(10 \mathrm{mg} / \mathrm{kg}$ by oral gavage), $\mathrm{Cr} 6+$ Selenium group and $\mathrm{Cr}$ $6+$ Vitamin E group. Biochemical, cytogenetic and sperm analysis were done to all groups. Results: Levels of cholesterol, triglyceride, micronucleus polychromatic erythrocyte, total sperm abnormality are increased while glucose, serum glutathione-s-transferase, testosterone, DNA and RNA contents, sperm viability and content decreased. Treatment with Se or vit.E improved all these effects. Conclusion: Hexavalent chromium induced changes in biochemical, cytogenetic and sperm analysis, which lead to disruption in reproductive cell functions. Se or vit. E has the ability for reduction of these deleterious effects. Recommendation: Since vitamin $\mathrm{E}$ and selenium have antioxidant properties and play vital role in preventing hexavalent chromium induced toxicity, dietary supplementation with them is recommended for exposed workers and general population.
\end{abstract}

Key words Hexavalent chromium, testicular toxicity, vitamin E (vit. E) and selenium (Se).

\section{Introduction}

$\mathrm{E}$ xposure to environmental genotoxicants is a major reason for the increased incidence of degenerative diseases in human. Genotoxic agents cause different types of DNA damage in somatic and germ cells, resulting in induction of mutation and genomic instability that is the hallmark of inducing cancer. So, evaluation of genotoxic potential of environmental chemicals is foremost for all toxicological studies (Hodjat et al., 2017).

The male reproductive system is highly sensitive to different environmental factors as drugs, pollution, radiation and toxicants (D'Cruz et al., 2010).
Therefore, the populations of industrialized countries have risk of decline fertility rates (Skakkebaek et al., 2016).

Heavy metal toxicity increased recently as a result of domestic, industrial and agricultural activities causing great threat to the ecosystem (Johnson and Radhakrishnan., 2016).

Testicular uptake of hexavalent chromium (Cr 6) and its reduction to trivalent chromium $(\mathrm{Cr} 3)$ is well known. Different studies attributed $\mathrm{Cr} 6$ testicular toxicity to oxidative stress (Aruldhas et al., 2005). 
Testicular membranes are highly rich in poly-unsaturated fatty acid so they are susceptible to oxidative stress. Oxidative damage to this polyunsaturated fatty acid affect membrane permeability causing congenital abnormalities in infants or functional alterations in adults (Anan et al., 2017).

There is global trend toward the use of natural substance present in medicinal plants and dietary plants as therapeutic antioxidants as a prophylactic action. The use of natural antioxidants would be a promising alternative for synthetic antioxidants in respect of low cost, highly compatible with dietary intake and no harmful effects on the human body (Mohammad, 2017).

Vitamin E (vit. E) is a natural component of bilayer membrane lipid and thus helps to maintain membrane stability (Acharya et al., 2004).

Vitamin $\mathrm{E}$ able to reduce the induced oxidative stress in various tissues by lowering malondialdehyde (MDA) levels and restoring the levels of glutathione (GSH), super oxide dismutase (SOD), and catalase (CAT) (Bharrhan et al., 2010).

Selenium is an essential micronutrient in various aspects of human health (MacFarquhar et al., 2010). It is one of antioxidants that is the essential in all biological systems, its presence in the active center of glutathione peroxidase (antioxidant enzyme) protects lipid membranes from oxidative damage by peroxides (Heikal et al., 2012).

So, the present work aimed to investigate the potential protective role of vitamin

$\mathrm{E}$ and selenium against sub-chronic toxicity of Hexavalent Chromium on the testes of adult male albino rats through biochemical, cytogenetic and Sperm analysis.

\section{Materials and methods The experimental animals:}

Sixty adult male albino rats, with average weight about 180-200 grams (g) for each rat, were used in this study. The animals were obtained from Helwan animal breeding farm, Cairo, Egypt.

They were maintained in stainless steel cages in a well-ventilated animal house at normal temperature $\left(22^{\circ} \mathrm{C} \pm 5^{\circ} \mathrm{C}\right)$ under a 12 : 12 -hour lightdark cycle. They were fed with normal feeding and water. They were kept under suitable conditions for one week for adaptation prior to the start of the experiment.

\section{Ethics statement}

The handling of animals was following the rules for the experimental research ethics approved by Research Ethics Committee at faculty of Medicine for Girls Al-Azhar University, Egypt.

\section{Tested Substance:}

- Hexavalent Chromium [Cr (6)]: In the form of potassium dichromate $\left(\mathrm{K}_{2} \mathrm{Cr}_{2} \mathrm{O}_{7}\right)$ powder purchased from Arab Company for Drug Industries and Medical Appliances, Abidin, Cairo, Egypt. Its solution was prepared by dissolving $140 \mathrm{mg}$ of $\mathrm{K} 2 \mathrm{Cr} 2 \mathrm{O} 7 \mathrm{in} 70 \mathrm{ml}$ of distilled water to give the estimated dose for each rat.

- Vitamin E ( $\alpha$-tocopherol): in the form of oil purchased from Cairo Company for Pharmaceutical and Chemical Industries, Shubra Cairo, Egypt.

- Selenium: in the form of selenium dioxide powder purchased from Arab Company for Drug Industries and Medical Appliances, Abidin, Cairo, Egypt. Selenium solution was prepared by dissolving $7 \mathrm{mg}$ of selenium in 28 $\mathrm{ml}$ of distilled water to give the estimated dose for each rat.

\section{Experimental design}

Rats were divided randomly into six groups (10 rats each) as follows:

1. Control group: rats were received normal feeding and distilled water only).

2. Selenium group: rats were given selenium by oral gavage $(0.5 \mathrm{mg} / \mathrm{kg}$ b.wt.) daily for six weeks according to Ognjanović et al., (2008).

3. Vitamin E group: rats were given vit. $\mathrm{E}$ by oral gavage $(200 \mathrm{mg} / \mathrm{kg}$ b.wt daily for 6

weeks according to Uzunhisarcikli et al.,2007.

4. Hexavalent chromium group [ $\mathrm{Cr}(6)]$ : rats were given $\mathrm{K}_{2} \mathrm{Cr}_{2} \mathrm{O}_{7}$ by oral gavage ( $8 \mathrm{mg} / \mathrm{kg}$ b.wt.) daily for 6 weeks according to Shati (2014).

$\begin{aligned} \text { 5. Cr (6) } & + \text { Se group: rats were } \\ & \text { given } \mathrm{K}_{2} \mathrm{Cr}_{2} \mathrm{O}_{7}+\text { selenium daily } \\ & \text { for } 6 \text { weeks (their same doses } \\ & \text { and route). }\end{aligned}$

6.Cr (6)+vit. E group: rats were given $\mathrm{K}_{2} \mathrm{Cr}_{2} \mathrm{O}_{7}+$ vit. E daily for 6 weeks (their same doses and route).

\section{Serum and tissue collection}

At the end of experimental period (6weeks), the animals were fasted overnight and then anaesthetized with diethyl ether inhalation and blood samples were collected by direct puncture of retroorbital venous plexus using glass capillaries in sterile separator. The blood samples were centrifuged at $2000 \mathrm{rpm}$ for $15 \mathrm{~min}$, to separate the sera then stored at $-20{ }^{\circ} \mathrm{C}$ for assessment of biochemical parameters.

After the collection of blood samples all animals were sacrificed by cervical dislocation, one testis homogenate (testis samples were homogenized in $25 \mathrm{~mL}$ saline-merthiolate-triton buffer at maximum speed $(27,000 \mathrm{rpm})$ for 2 minutes and used immediately for counting), both epididymis and both femora from each rat were dissected for cytogenetic analysis, sperm morphology and sperm count. All 
biochemical, cytogenetic analysis, sperm morphology and sperm count were done at Cell Biology Department of National Research Center in Dokki (Cairo).

Both femurs were dissected and bone marrow was flushed from the femoral cavity with fetal calf serum and then smeared on clean slides (Valette et al., 2002). The slides were air-dried and fixed in absolute methanol for 5 minutes, followed by staining in 5\% solution of Giemsa at $\mathrm{pH} 6.8$ for 20 minutes (Dśouza et al., 2002).The number of 2000 polychromatic erythrocytes (PCEs) were scored per animal and the number of micronucleated PCEs were recorded by using high power of the light microscope.

\section{I-Biochemical evaluation}

1) Lipid profile levels including cholesterol and triglyceride in testicular tissue according to Richmond, (1974) and Fossati and Prencipe, (1982) respectively.

2) Glucose level in testicular tissue according to (Trinder, 1969).

3) Antioxidant enzymes in the form of serum glutathione -s-transferase level according to (Habig et al., 1974).

4) The serum level of testosterone according to (Rajkowski et al., 1977)

\section{II-Cytogenetic analysis}

1. The total DNA and RNA contents in testicular tissue according to Dische and Schwartz (1954) \& Dische, (1957) respectively after doing nucleic acids extraction according to (Pears, 1985).

2. Micronucleus polychromatic erythrocyte (MNPCEs) in femur bone marrow to detect DNA damage according to (Salamone et al., 1980).

\section{III- Sperm analysis}

Sperm morphology and sperm count were evaluated according to Wyrobek et al., (1984).

\section{Statistical Analysis}

All data were statistically expressed as means $\pm \mathrm{SD}$ and compared using the one-way analysis of variance (ANOVA) followed by Tukey's post hoc test. Level of probability (P-value) less than 0.05 is used as the criterion of significance. Statistical analysis was performed using the Statistical Package for the Social Sciences, Version 22 for Windows (California, USA ).

\section{Results}

Lipid profile levels including (cholesterol and triglyceride) were significantly increased in $\mathrm{Cr}$ (6) treated groups compared to control group. Coadministration of $\mathrm{Cr}$ (6) with vit.E caused significant decrease in cholesterol level only while Se caused significant decrease in both cholesterol and triglyceride levels (table 1).

Regarding glucose level in testicular tissue; data in table (2) revealed that, animals treated with $\mathrm{Cr}$ (6) showed significant decrease in the testicular glucose level compared to control group. Coadministration of either vit.E or $\mathrm{Se}$ caused insignificant increase in testicular glucose level.

There was high significant decrease in total content of DNA and RNA in testicular tissue in $\mathrm{Cr}$ (6) treated groups as compared to control group. Both Se or vit. E showed improvement of the total content of DNA and RNA in testicular tissue with better effect in the vit. E group (table 3).

Animals treated with $\mathrm{Cr}(6)$ showed significant decrease in the serum testosterone hormone level compared to control group. Coadministration of either vit.E or Se caused significant increase in its level with better effect in the vit. E group (table 4).

Regarding the antioxidant glutathione -stransferase $\mathrm{Cr}$ (6) showed significant decrease in its level; both vit.E and Se caused significant increase in its level with better effect in the vit. E group (table 4).

Table (5) and fig (2) showed that animals treated with $\mathrm{Cr}(6)$ have significant increase in the frequencies of micronuclei polychromatic erythrocytes in bone marrow cells compared to control group in (fig.1). Co-administration of Se caused significant decrease in its frequencies but the effect of vit. $\mathrm{E}$ was insignificant.

Table (6) illustrated that rats expos (6) showed significant increase in sperm abnormalities in form of amorphous or banana head and coiled tail compared to control group. Co administration of either $\mathrm{Se}$ or vit. $\mathrm{E}$ significantly decreased these abnormalities with better effect in the vit. E group.

Also, a significant reduction in sperm count was observed in rats exposed to $\mathrm{Cr}$ (6) compared to control rats. In addition, concomitant administration of Se or vit. E significantly improved total sperm count with better effect to vit. $E$.

As regarding viability rate, it was observed that rats treated with $\mathrm{Cr}$ (6) showed significant decrease in the number of living sperms as compared to control group. While administration of Se or vit $\mathrm{E}$ improved viability rate with better effect to vit. 
Table (1): ANOVA statistical analysis for changes in lipid profile levels (cholesterol and triglyceride) induced by $\mathrm{Cr}$ (6) sub-chronic toxicity in testes of adult male albino rats and the possible protective role of Se or vit. $\mathrm{E}$

\begin{tabular}{|c|c|c|}
\hline $\begin{array}{c}\text { Groups } \\
\text { n=10rats/group }\end{array}$ & $\begin{array}{c}\text { Cholesterol } \\
\mathbf{m g} / \mathbf{g}\end{array}$ & $\begin{array}{c}\text { Triglycerides } \\
\text { mg/g }\end{array}$ \\
\hline Control group & Mean \pm S.D. & Mean \pm S.D. \\
\cline { 2 - 3 } & $157.626 \pm 2.464$ & $54.796 \pm 3.550$ \\
\hline Vit. E group & $157.037 \pm 2.373^{\mathrm{a}}$ & $53.782 \pm 2.818^{\mathrm{a}}$ \\
\hline Se group & $157.270 \pm 2.345^{\mathrm{a}}$ & $54.589 \pm 2.862^{\mathrm{a}}$ \\
\hline $\mathbf{C r}(\mathbf{6})$ toxicity & $262.880 \pm 4.850^{* *}$ & $97.67 \pm 5.619^{* *}$ \\
\hline $\mathbf{C r}(6)+v i t . E$ & $161.730 \pm 1.651^{*}$ & $56.278 \pm 5.619^{\mathrm{a}}$ \\
\hline $\mathbf{C r}(\mathbf{6})+$ Se & $161.889 \pm 1.664^{*}$ & $57.276 \pm 2.837^{*}$ \\
\hline
\end{tabular}

Se= selenium; vit. E = vitamin $E ; C r(6)=$ hexavalent chromium; $n=$ number; $S . D .=$ standard deviation; comparison is done with the control group: $a=$ non-significant $p>0.05 * *=$ highly significant $(P \leq 0.01) . *=$ significant $(P \leq 0.05)$

Table (2): ANOVA statistical analysis for changes in glucose level induced by $\mathrm{Cr}$ (6) sub-chronic toxicity in testes of adult male albino rats and the possible protective role of Se or vit. $E$

\begin{tabular}{|c|c|}
\hline Groups & Glucose $\mathbf{~ m g} / \mathbf{g}$ \\
\cline { 2 - 2 } n=10rats/group & Mean \pm S.D. \\
\hline Control group & $224.16 \pm 2.78$ \\
\hline Vit. E group & $216.21 \pm 8.03^{\mathrm{a}}$ \\
\hline Se group & $213.53 \pm 7.70^{\mathrm{a}}$ \\
\hline $\mathbf{C r}(\mathbf{6})$ toxicity & $104.833 \pm 3.833^{* *}$ \\
\hline $\mathbf{C r}(\mathbf{6})+$ vit.E & $173.595 \pm 1.940^{\mathrm{a}}$ \\
\hline $\mathbf{C r}(6)+$ Se & $173.755 \pm 1.952^{\text {a }}$ \\
\hline
\end{tabular}

Se= selenium; vit. E= vitamin $E ; C r(6)=$ hexavalent chromium; $n=$ number; S.D. $=$ standard deviation; comparison is done with the control group: $a=$ non-significant $p>0.05 * *=$ highly significant $(P \leq 0.01)$. $*=$ significant $(P \leq 0.05)$

Table (3): ANOVA statistical analysis for changes in the total DNA and RNA contents induced by Cr (6) subchronic toxicity in testes of adult male albino rats and the possible protective role of Se or vit. $E$

\begin{tabular}{|c|c|c|}
\hline $\begin{array}{c}\text { Groups } \\
\text { n=10rats/group }\end{array}$ & DNA $(\mathbf{m g} / \mathbf{g m}$ tissue $)$ & RNA $(\mathbf{m g} / \mathbf{g m ~ t i s s u e )}$ \\
\cline { 2 - 3 } Control group & Mean \pm S.D. & $0.313 \pm 0.018$ \\
\hline Vit. E group & $0.409 \pm 0.16$ & $321 \pm 0.031^{\mathrm{a}}$ \\
\hline Se group & $0.442 \pm 0.028^{\mathrm{a}}$ & $0.319 \pm 0.013^{\mathrm{a}}$ \\
\hline $\mathbf{C r}(\mathbf{6})$ toxicity & $0.414 \pm 0.015^{\mathrm{a}}$ & $0.207 \pm 0.013^{* *}$ \\
\hline $\mathbf{C r}(\mathbf{6})+v i t . \mathbf{E}$ & $0.225 \pm 0.25^{* *}$ & $0.269 \pm 0.021^{*}$ \\
\hline $\mathbf{C r}(6)+S e$ & $0.392 \pm 0.067^{*}$ & $0.252 \pm 0.023^{*}$ \\
\hline
\end{tabular}

$S e=$ selenium; vit. $E=$ vitamin $E ; C r(6)=$ hexavalent chromium; $n=$ number; S.D. = standard deviation; comparison is done with the control group: $a=$ non-significant $p>0.05 * *=$ highly significant $(P \leq 0.01)$. $*=$ significant $(P \leq 0.05)$

Table (4): ANOVA statistical analysis for changes in the serum levels of testosterone hormone and antioxidant glutathione -s-transferase induced by $\mathrm{Cr}$ (6) sub-chronic toxicity in adult male albino rats and the possible protective role of Se or vit. $\mathrm{E}$

\begin{tabular}{|c|c|c|}
\hline $\begin{array}{c}\text { Groups } \\
\text { n=10rats/group }\end{array}$ & Testosterone ng/ul & glutathione -s-transferase (U/L) \\
\cline { 2 - 3 } Control group & Mean \pm S.D. & $1496.154 \pm 108.254$ \\
\hline Vit. E group & $15.49 \pm 0.631$ & $1530.512 \pm 130.087^{\mathrm{a}}$ \\
\hline Se group & $15.81 \pm 2.161^{\mathrm{a}}$ & $1513.107 \pm 122.971^{\mathrm{a}}$ \\
\hline $\mathbf{C r}(6)$ toxicity & $15.51 \pm 0.972^{\mathrm{a}}$ & $527.254 \pm 66.985^{* *}$ \\
\hline $\mathbf{C r}(6)+$ vit.E & $7.45 \pm 0902^{* *}$ & $1259.664 \pm 52.764^{*}$ \\
\hline $\mathbf{C r}(6)+$ Se & $13.8 \pm 0.65^{*}$ & $1245.559 \pm 50.603^{*}$ \\
\hline
\end{tabular}

Se= selenium; vit. E= vitamin $E ; C r(6)=$ hexavalent chromium; $n=$ number; S.D. $=$ standard deviation; comparison is done with the control group: $a=$ non-significant $p>0.05 * *=$ highly significant $(P \leq 0.01)$. $=$ significant $(P \leq 0.05)$ 
Table (5): ANOVA statistical analysis for changes in the frequencies of micronuclei polychromatic erythrocytes in bone marrow cells (no. of examined cells $=2000$ in each group) induced by $\mathrm{Cr}(6)$ sub-chronic toxicity in adult male albino rats and the possible protective role of Se or vit. $\mathrm{E}$

\begin{tabular}{|c|c|}
\hline $\begin{array}{c}\text { Groups } \\
\text { n=10rats/group }\end{array}$ & Micro nucleated polychromate erythrocyte (MNPL) \\
\hline Control group & $9.2 \pm 1.778$ \\
\hline Vit. E group & $8.3 \pm 1.792^{\mathrm{a}}$ \\
\hline Se group & $8.5 \pm 1.5^{\mathrm{a}}$ \\
\hline $\mathbf{C r}(\mathbf{6})$ toxicity & $24.6 \pm 3.040^{* *}$ \\
\hline $\mathbf{C r}(6)+$ vit.E & $10.311 \pm 1.925^{\mathrm{a}}$ \\
\hline $\mathbf{C r}(6)+$ Se & $11.60 \pm 1.333^{*}$ \\
\hline
\end{tabular}

MNPL: micro nucleated polychromate erythrocyte, Se= selenium; vit. $E=$ vitamin $E ; C r(6)=$ hexavalent chromium; $n=$ number; $S . D .=$ standard deviation; comparison is done with the control group: $a=$ non-significant $p>0.05 * *=$ highly significant $(P \leq 0.01)$. ${ }^{*}$ significant $(P \leq 0.05)$.

Table (6): ANOVA statistical analysis for changes in the Sperm (sperm abnormality in head and tail, total abnormality, total content and viability\%) induced by $\mathrm{Cr}(6)$ sub-chronic toxicity in adult male albino rats and the possible protective role of Se or vit. $E$

\begin{tabular}{|c|c|c|c|c|c|c|}
\hline \multirow[b]{2}{*}{$\begin{array}{c}\text { Groups } \\
\text { n=10rats/group }\end{array}$} & \multicolumn{3}{|c|}{ Sperm abnormality } & \multirow{2}{*}{$\begin{array}{l}\text { Total abnormality } \\
\text { Mean } \pm \text { SD }\end{array}$} & \multirow[b]{2}{*}{$\begin{array}{l}\text { Total } \\
\text { sperm } \\
\text { count } \\
\text { Millions/gm } \\
\text { testes } \\
\text { Mean } \pm \text { SD }\end{array}$} & \multirow{2}{*}{$\begin{array}{l}\text { Viability } \\
\% \\
\text { (Live/ } \\
\text { dead+live) } \\
\text { Mean } \pm \text { SD }\end{array}$} \\
\hline & $\begin{array}{c}\text { Amorphous head } \\
\text { Mean } \pm \text { SD }\end{array}$ & $\begin{array}{c}\text { Banana head } \\
\text { Mean } \pm \text { SD }\end{array}$ & $\begin{array}{l}\text { Coiled tail } \\
\text { Mean } \pm \text { SD }\end{array}$ & & & \\
\hline Control group & $2.6 \pm 1.2$ & $1.5 \pm 1.290$ & $1.3 \pm 0.9$ & $5.1 \pm 2.41$ & $\begin{array}{c}33.150 \pm \\
1.934\end{array}$ & $\begin{array}{c}73.8 \% \pm \\
4.020\end{array}$ \\
\hline Vit. E group & $2.4 \pm 1.28^{\mathrm{a}}$ & $1.2 \pm 1.668^{\mathrm{a}}$ & $\begin{array}{c}1.1 \pm 0.793 \\
\mathrm{a}\end{array}$ & $4.7 \pm 1.921^{\mathrm{a}}$ & $\begin{array}{c}35.825 \pm \\
2.068^{\mathrm{a}}\end{array}$ & $\begin{array}{l}75.9 \% \\
\pm 3.936^{a}\end{array}$ \\
\hline Se group & $2.5 \pm 1.305^{\mathrm{a}}$ & $1.3 \pm 1.269^{\mathrm{a}}$ & $\begin{array}{c}1.2 \pm 0.780 \\
\mathrm{a}\end{array}$ & $5 \pm 2.002^{a}$ & $\begin{array}{c}34.200 \pm \\
1.589^{\mathrm{a}}\end{array}$ & $\begin{array}{c}74.8 \% \pm \\
4.019^{\mathrm{a}}\end{array}$ \\
\hline $\operatorname{Cr}(6)$ toxicity & $13.4 \pm 2.245 * *$ & $12.9 \pm 2.385 * *$ & $\begin{array}{c}12.5 \pm \\
3.775 * *\end{array}$ & $38.8 \pm 4.214 * *$ & $\begin{array}{c}23.400 \pm \\
1.431 * *\end{array}$ & $\begin{array}{c}57 \% \pm \\
3.742 * *\end{array}$ \\
\hline $\operatorname{Cr}(6)+v i t . E$ & $3.7 \pm 1.418^{*}$ & $2.3 \pm 1.1^{*}$ & $\begin{array}{c}1.9 \pm \\
1.446 *\end{array}$ & $7.9 \pm 3.256^{*}$ & $\begin{array}{c}31.250 \pm \\
1.799 *\end{array}$ & $\begin{array}{c}70.9 \% \pm \\
2.914 *\end{array}$ \\
\hline $\mathrm{Cr}(6)+\mathrm{Se}$ & $4 \pm 1.732 *$ & $2.5 \pm 1.66^{*}$ & $\begin{array}{c}2.4 \\
\pm 1.491 *\end{array}$ & $8.9 \pm 3.789 *$ & $\begin{array}{c}29.150 \pm \\
1.125 *\end{array}$ & $\begin{array}{c}69.5 \% \pm \\
3.772 *\end{array}$ \\
\hline
\end{tabular}

$S e=$ selenium; vit. E= vitamin $E ; C r(6)=$ hexavalent chromium; $n=$ number; S.D. $=$ standard deviation; comparison is done with the control group: $a=$ non-significant $p>0.05 * *=$ highly significant $(P \leq 0.01)$. ${ }^{*}=$ significant $(P \leq 0.05)$

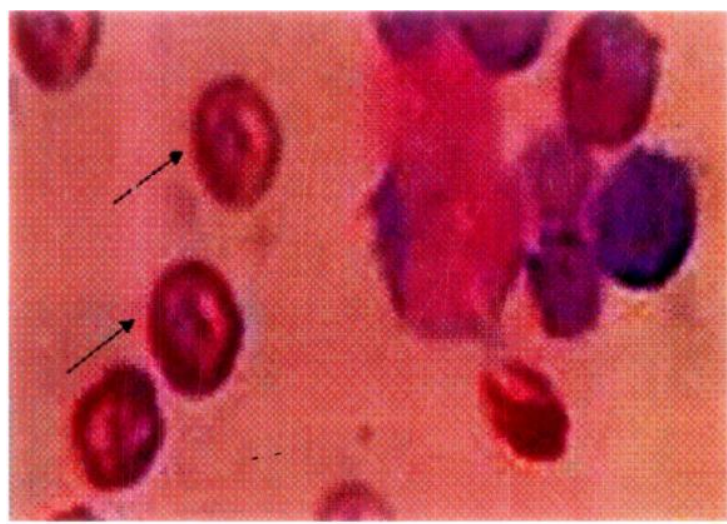

Figure (1) Normal polychromatic erythrocytes in bone marrow of control (Giemsa stain, $x$ 100)

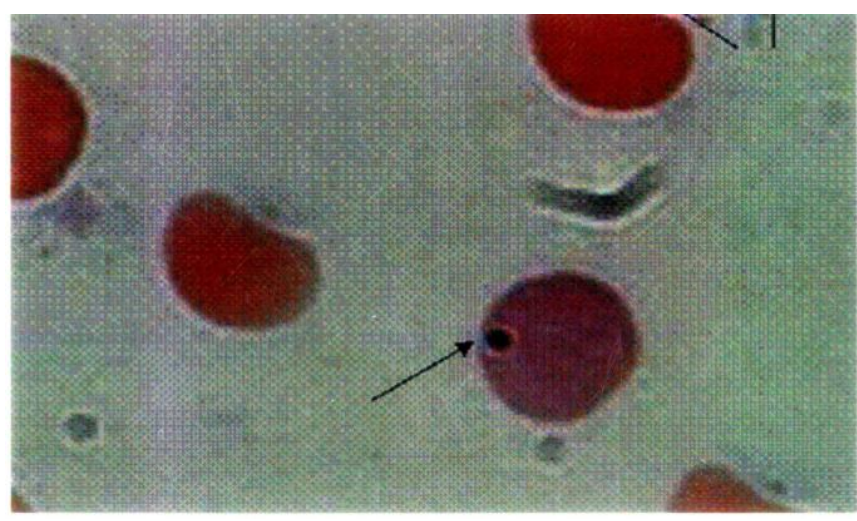

Figure (2) Micro nucleated polychromatic erythrocytes in bone marrow of rat exposed to $\mathrm{Cr}(6)$ intoxication (Giemsa stain, $x$ 100) 


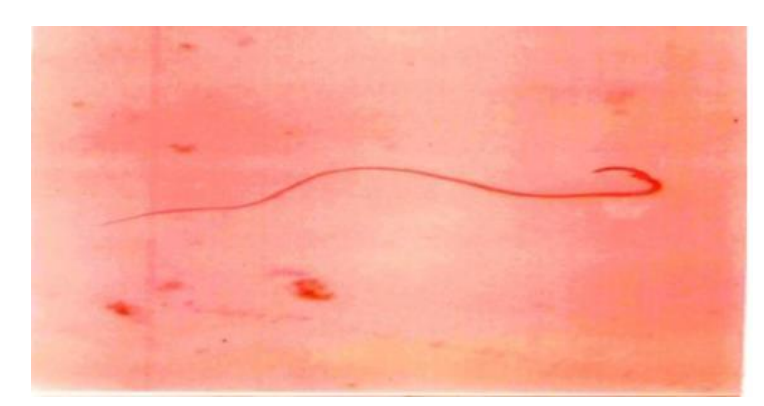

Figure (3) A photomicrograph of normal sperm morphology showing head and tail normal in control rats (Eosin stain, $x$ 400)

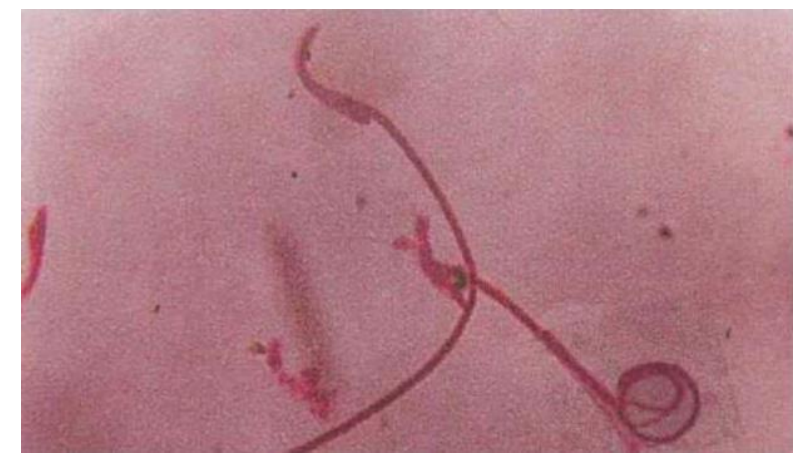

Figure (5): A photomicrograph of sperm abnormality showing coiled tail in rats exposed to $\mathrm{Cr}$ (6) (Eosin stain, $x$ 400).

\section{Discussion}

Chromium compounds are extremely toxic (Jabbońska-Czapla, 2014). It is widely used in industry and its exposure has been involved in many disorders as cytotoxicity, genotoxicity and nephrotoxicity (Fatima and Mahmood, 2007). Numerous epidemiological studies have reported a high incidence of lung cancer among workers exposed occupationally to $\mathrm{Cr}(6)$ by inhalation also chromate is a very common contaminant in drinking water (Sun et al., 2015).

Chromium 6 produced testicular lesions and in turn spermatogenic arrest, and so reducing epididymal sperm number (Afonne et al., 2002).

Selenium (Se) is an essential component of many enzymes as selenoprotein $\mathrm{P}(\mathrm{SeP})$, glutathione peroxidase (GPx), and thioredoxin reductase (TR) (Saito et al., 2003). It is known, that Se has protective role against the toxic actions of heavy metals (Ognjanović et al., 2008).

Vitamin E ( $\alpha$-tocopherol), is a chain breaking antioxidant existing in plasma and cell membranes. It eliminates alkoxyl radicals and lipid peroxyl, inhibits the chain reaction of lipid peroxidation and enhances the production of scavenger antioxidant enzymes (Balakrishnan et al., 2013).

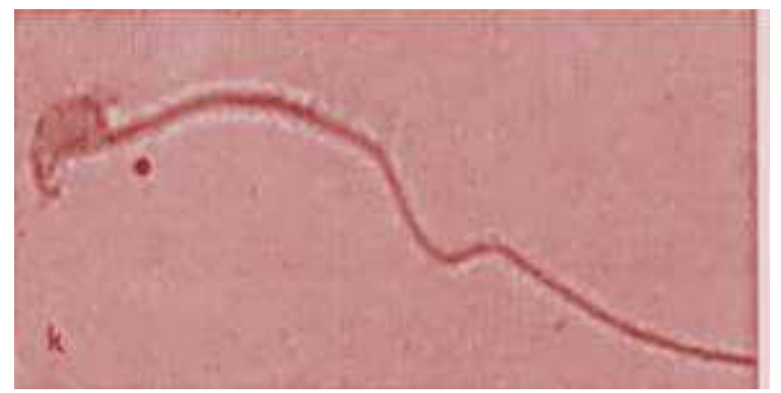

Figure (4) A photomicrograph of sperm head abnormality showing amorphous head in rats exposed to $\operatorname{Cr}(6)$ (Eosin stain, $x$ 400)

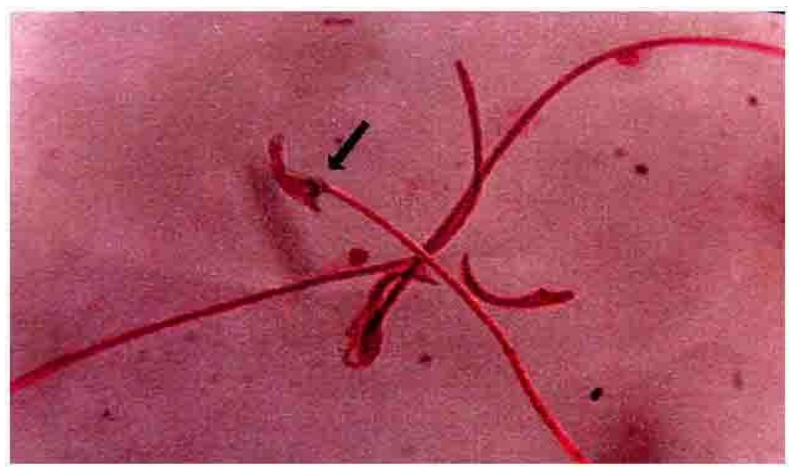

Figure (6): A photomicrograph of sperm abnormality showing bannana head in rats exposed to $\mathrm{Cr}$ (6) (Eosin stain, $\mathrm{x} 400$ ).

So, the present work aimed to investigate the potential protective role of vitamin $\mathrm{E}$ and selenium against sub-chronic toxicity of hexavalent chromium on the testes of adult male albino rats through biochemical, cytogenetic and Sperm analysis.

In the current study, $\mathrm{Cr}$ (6) significantly increased both cholesterol and triglyceride levels in the testes of adult male albino rats. While the testicular glucose level showed significant decrease. Co administration of $\mathrm{Cr}$ (6) with vit.E succeeded to decrease cholesterol level only, while Se caused significant decrease in both cholesterol and triglyceride levels. Regarding glucose either vit.E or Se insignificantly increased its level.

These results were coincided with Shil and Pal (2017) who found marked decrease in liver glycogen in mice model and explained this as a result of renal glycosuria that caused by impairment of renal reabsorption of glucose. Also, Ahmad et al. (2011) who reported that $\mathrm{Cr}$ (6) exposure causes hypoglycemia.

Myers et al. (2011) explained the defect in the glycolytic activity by $\operatorname{Cr}(6)$ as a result of conversion of hexavalent $\mathrm{Cr}(6)$ to trivalent $\mathrm{Cr}$-ATP complex that acts as competitive inhibitor for different ATP- 
dependent enzymes and several kinases involved in glycolysis.

While Saha et al. (2017) found increase in plasma glucose and cholesterol levels of the exposed rats to $\mathrm{Cr}$ (6) and Yousif and Ahmed (2009) attributed that to defect in utilization of these nutrients at tissue level due to toxicity of $\mathrm{Cr}(6)$.

Chromium (6) increased cholesterol level in cells by upregulating cholesterol-synthesizing enzymes (Guo et al., 2013). Accumulation of cholesterol and triglyceride in chromium-exposed tissue resulted in fatty infiltration of that tissue (Shil and Pal, 2017).

Ahmad et al. (2011) reported that as a compensatory mechanism of carbohydrate and protein depletion in $\mathrm{Cr}(6)$ intoxication it may induce increased expression of fatty acid synthase and stimulate isocitrate dehydrogenase in the liver tissue to promote lipogenesis.

Hypoglycemia stimulates cortisol secretion causing breakdown of fat and mobilizes free fatty acids to the liver, promoting the synthesis of triglyceride and cholesterol (Wang et al., 2012)

In the current study there was high significant decrease in total content of DNA and RNA in testicular tissue in $\mathrm{Cr}$ (6) treated groups as compared to control group. Both Se or vit. E showed improvement of the total content of DNA and RNA in testicular tissue with better effect in the vit. E group. These results were in agreement with Elgharabawy and Emara (2014) who reported that $\mathrm{Cr}$ (6) increased production of hydroxyl radicals resulting in appreciable DNA damage.

Aruldhas et al. (2005) supported these results as they stated that direct interaction of reactive chromium intermediates with DNA leading to DNAchromium binding, DNA-protein crosslinks and DNA-DNA crosslinks and they added that interaction of chromium with GSH results in strand breaks and chromium-DNA binding. Chen et al. (2012) attributed the DNA damage to the reactive oxygen species ROS that can convert fatty acids to toxic lipid peroxides and could damage every major cellular component.

Regarding the antioxidant glutathione -stransferase (GST) in the present study; $\mathrm{Cr}$ (6) showed significant decrease in its level; both vit.E and Se caused significant increase in its level with better effect in the vit. E group.

This result was in accordance with kim et al. (2012) who found significant decrease in GST in the testicular and epididymal tissues.

However, Aruldhas et al. (2005) found increased concentration of GSH in the testes of monkeys exposed to chromium and they attributed that to its action as a protector of spermatogonia.
Micronucleus (MN), chromatin-containing bodies, a microscopically visible round or oval cytoplasmic chromatin mass in the extranuclear vicinity, originate from aberrant mitosis and consists of chromatid fragments, eccentric chromosomes, or whole chromosomes, that failed to reach spindle poles during mitosis. The micronuclei ( $\mathrm{MN})$ assay is a minimally invasive method as an evidence of chromosomal damage (Arul et al., 2017). It is used to detect the genotoxic effects of environmental mutagens (Shruthi and Vijayalaxmi, 2016). The incidence of micronucleated polychromatic erythrocytes (MnPCEs), caused appearance of some changes in polymorphism band patterns, and induced different histopathological lesions in the livers, kidneys, and testis (Khalil et al., 2008).

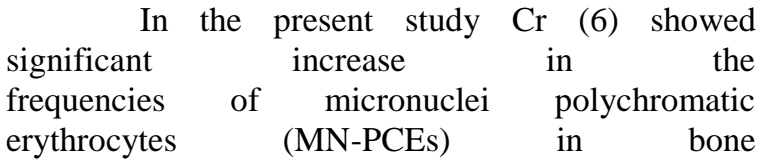
marrow cells compared to control group. Coadministration of Se caused significant decrease in its frequencies but the effect of vit. $\mathrm{E}$ was insignificant.

This result was in agreement with GarcíaRodríguez et al. (2013) who stated that the genotoxicity of $\mathrm{Cr}$ (6) was noted by significant increase in MN-PCEs. And they added that free radical formation may play an important role in $\mathrm{Cr}$ (6)mediated DNA damage and apoptosis.

Nassar et al. (2012) explained the formation of micronuclei in bone marrow cells in $\mathrm{Cr}$ (6) toxicity to chromosomal breakage.

Animals that treated with $\mathrm{Cr}$ (6) in the current work showed significant decrease in the serum testosterone hormone level compared to control group. After co-administration of either vit.E or Se its level significantly increased and the better effect was with vit. E. These results were supported by Holdcraft and Braun (2004) who stated that $\mathrm{Cr}$ exposure resulted in decline of antioxidants as SOD, catalase and GSH activities and increased production of ROS beyond the accepted limit resulting in defect in Leydig cell functions that plays important role in decreasing testosterone production.

Elgharabawy and Emara (2014) reported that $\mathrm{Cr}$ activates hypothalamo-pituitary adrenal axis which in turn stimulates rapid release of corticotropin releasing hormone, corticotropin and glucocorticoids, resulting in a fall of plasma $\mathrm{LH}$ and testosterone levels.

Also, $\mathrm{Cr}$ induces generation of ROS and disruption of blood-testis barrier with consequent accumulation of $\mathrm{Cr}$ in the testis (Acharya et al., 2004).

Data of the present study illustrated that rats exposed to $\mathrm{Cr}$ (6) showed significant increase in sperm 
abnormalities in the form of amorphous or banana head and coiled tail compared to control group. Coadministration of either Se or vit. E significantly decreased these abnormalities with better effect in the vit. E group. This was supported by Aruldhas et al. (2005) who found that occupational exposure to $\mathrm{Cr} 6$ lead to abnormal semen quality in men.

These abnormalities could be due to epididymal dysfunction and hyperlipidemia that may alter the sperm maturation process as mentioned by Biswas et al. (2017).

In the current work, a significant reduction in sperm count was observed in rats exposed to $\mathrm{Cr}$ (6) compared to control rats. In addition, concomitant administration of Se or vit. E significantly improved total sperm count with better effect to vit. E.

This result coincided with kim et al. (2012) who found that $\mathrm{Cr}(6)$ increased the sperm abnormality and reduced sperm count. And this could be due to lipid peroxidation that cause DNA and protein damage, which in turn led to sperm degradation and infertility as mentioned by Elgharabawy and Emara (2014).

Also, Vernet et al. (2004) stated that sperm cell is more susceptible to peroxidative damage, because of its high concentration of polyunsaturated fatty acids and low antioxidant capacity. Chromium exposure interferes with spermatogenesis and reduces the epididymal sperm number (Afonne et al., 2002)

Johnson and Radhakrishnan (2016) in their study observed testicular impairment and inhibition of spermatogenesis and attributed that to the direct cytotoxic effects of heavy metals as well as disruption of endocrine function.

Hatamoto et al. (2006) attributed the reduction in semen quality, decreasing sperm count and motility to ROS production, they can also increase sperm defects and impairment of antioxidant synthesis. While, Elgharabawy and Emara (2014) attributed this to the ability of $\mathrm{Cr}(6)$ to induce DNA damage in germ cells leading to altered sperm morphology.

As regarding viability rate in the present study, it was observed that $\mathrm{Cr}$ (6) showed significant decrease in the number of living sperms as compared to control group. While administration of Se or vit. E improved viability rate with better effect to vit. E.

Aruldhas et al (2005) reported that at different stages of germ cell development; it requires some nutrients, as lactate, pyruvate, fatty acids and regulatory peptides, $\mathrm{Cr}$ (6) toxicity affects the supply of such nutrients resulting in premature germ cells death. Production of ROS causes loss of sperm motility by decomposing sperm plasma membrane, due to rapid loss of intracellular ATP leading to damage in the sperm flagellum. Also, activity of Na+-K+-ATPase is highly sensitive to ROS, thus depletion of Na+-K+-ATPase can be a good reason for the reduction of sperm motility (Elgharabawy and Emara, 2014).

Marouani et al. (2017) stated that $\mathrm{Cr}$ (6) produces morphological alteration of the seminiferous tubule with enlarged intracellular spaces, prominent decline in sperm count and motility, and toxic changes in epididymal spermatozoa and Leydig cells' architecture.

Endogenous and exogenous antioxidants could protect tissues and cells from destructive effects of ROS and other free radicals (Hosseini et al., 2012) and this supported what was observed after administration of $\mathrm{Se}$ or vit $\mathrm{E}$ in the current study.

\section{Conclusion}

Considering the results obtained from the present study it can be concluded that, exposure of rats to $\mathrm{Cr}$ (6) affect the testes and induced changes in the studied biochemical and cytogenetic parameters, which will lead to disruption in reproductive cell functions. In addition, the antioxidative effect of Se or vit $\mathrm{E}$ play an important role in testes protection from cytogenotoxic effects of $\mathrm{Cr}$ (6) and it is beneficial in lowering the sperm abnormalities.

\section{Recommendation}

Where the controlling process to limit uses of $\mathrm{Cr}$ (6) is not easy to reach so, there is a need to in rich our diet with antioxidants compounds as $\mathrm{Se}$ or vit $\mathrm{E}$ to prevent cellular damage that occur due to oxidative stress.

\section{References}

Acharya R., Mishra M., Mishra I. and Tripathy R.R. (2004): Potential role of vitamins in chromium induced spermatogenesis in Swiss mice. Enviro. Toxicol. Pharmacol., 15: 5359.

Afonne O., Orisakwe O., Ima-Obong A. and David D. (2002): Zinc protects chromium-induced testicular injury in mice. Indian Journal of Pharmacology; 34: 26-31

Ahmad MK, Syma S, Mahmood R (2011): Cr (6) induces lipid peroxidation, protein oxidation and alters the activities of antioxidant enzymes in human erythrocytes. Biol Trace Elem Res; 144:426-435

Anan HH, Wahba NS, Abdallah MA, Mohamed DA. (2017): Antioxidant Effect of Selenium on Hepatotoxicity Induced by Chlorpyrifos on Male Rats. Int. J. Pharm. Pharm. Sci., 4 (4): 603-609.

Arul P, Shetty S, Masilamani S, Akshatha Cand Naveen Kumar B. (2017): Evaluation of Micronucleus in Exfoliated Buccal Epithelial Cells Using Liquid-Based Cytology Preparation in Petrol Station 
Workers. Indian Journal of Medical and Paediatric Oncology; 38(3): 273-6.

Aruldhas M.M., Subramanian S., Sekar P., Vengatesh G. (2005): Chronic chromium exposureinduced changes in testicular histoarchitecture are associated with oxidative stress: study in a non-human primate (Macaca radiata Geoffroy). Human reproduction;20(10):2801-2813.

Balakrishnan R., Kumar C.S.S., Rani M.U., Srikanth M.K., Boobalan G. and Reddy A.G. (2013): An evaluation of the protective role of $\alpha$-tocopherol on free radical induced hepatotoxicity and nephrotoxicity due to chromium in rats. Indian J. Pharmacol., 45(5): 490-495.

Bharrhan S., Chopra K. and Rishi P., (2010): Vitamin $\mathrm{E}$ supplementation modulates endotoxin induced liver damage in a rat model. Am. J. Biomed. Sci., 2: 51-62.

Biswas A, D'souza U and Bhat S. (2017): Dietary hypercholesterolemia induces oxidative stress challenging spermatogenesis in rat model: a link to possible infertility. Int $\mathbf{J}$ Pharm Sci Res.; 8 (12): 5065-71.

Chen Z, Jiang H, Wan Y, Bi C and Yuan Y. (2012): $\mathrm{H} 2 \mathrm{O} 2$-induced secretion of tumor necrosis factor-a evokes apoptosis of cardiac myocytes through reactive oxygen speciesdependent activation of $\mathrm{p} 38$ MAPK. Cytotecnology; 64:65-73.

D'Cruz S, Vaithinathan S, Jubendradass R, and Mathur P. (2010): Effects of plants and plant products on the testis. Asian Journal of Andrology; 12: 468-79.

Dische and Schwartz. (1954): Estimation of nucleic acids. In: Methods of Biochemical analysis. Vol. I. Glick D (ed). New York: Interscience Publishers Inc. 299. Dische. (1957): Determination of pentoses. In: Methods in Enzymology. Vol. III. Colourick SP and Kaplan NO (eds) New York: Academic Press Inc. p: 88.

Dśouza U, Zain A and Raju S. (2002): Genotoxic and cytotoxic effects bone marrow of rats

exposed to low dose of paraquat via the dermal route. Mutat. Res.; 581:187-90.

Elgharabawy R. M. and Emara A. M.( 2014): The protective effect of Panax ginseng against chromium picolonate induced testicular changes. African Journal of Pharmacy and Pharmacology; 8(12): 346-355.

Fatima S. and Mahmood R. (2007): Vitamin C attenuates potassium dichromate induced nephrotoxicity and alterations in renal brush border membrane enzymes and phosphate transport in rats. Clin. Chim. Acta., 386(12): 94-99.

Fossati P and Prencipe L. (1982): Serum triglycerides determined colorimetrically with an enzyme that produces hydrogen peroxide. Clin Chem.; 28(10):2077-80

García-Rodríguez M. , Carvente-Juárez M. , and Altamirano-Lozano M.( 2013): Antigenotoxic and Apoptotic Activity of Green Tea Polyphenol Extracts on Hexavalent Chromium-Induced DNA Damage in Peripheral Blood of CD-1 Mice: Analysis with Differential Acridine Orange/Ethidium Bromide Staining. Oxid Med Cell Longev; 486419.

Guo L, Xiao Y and Wang Y (2013): Hexavalent chromium-induced alteration of proteomic landscape in human skin fibroblast cells. J Proteome Res 5:3511-3518

Habig W., Jakoby WB and Pabst M.W.(1974): Glutathione S-transferases. The first enzymatic step in mercapturic acid formation. J Biol Chem.;249(22):7130-9.

Hatamoto LK, Baptista Sobrinho CA, Nichi M, Barnabe VH, Barnabe RCand Cortada CN (2006): Effects of dexamethasone treatment (to mimic stress) and Vitamin $\mathrm{E}$ oral supplementation on the spermiogram and on seminal plasma spontaneous lipid peroxidation and antioxidant enzyme activities in dogs. Theriogenology 66(6-7):1610-1614.

Heikal T.M., EL-Sherbiny M., Hassan S.A., Arafa A. and Ghanem H.Z. (2012): Histological and immunohistochemical study of cyclophosphamide effect on adult rat testis. International Journal of Scientific Reports; 3 (2):39-48.

Hodjat M, Baeeri M, Rezvanfar M, Rahimifard M, Gholami M and Abdollahi M.(2017): On the mechanism of genotoxicity of ethephon on embryonic fibroblast cells. Toxicology Mechanism \& Method; 27(3): 173-80.

Holdcraft R.W. and Braun R.E.( 2004): Androgen receptor function is required in Sertoli cells for the terminal differentiation of haploid spermatids. Development.;131(2):459-67.

Hosseini A, Pakdel F, Ahmadi A and Zare S (2012). Beneficial Effects of American Ginseng on Epididymal Sperm Analyses in Cyclophosphamide Treated Rats. Cell J. $14: 2$.

Hsieh, Y. Y., Chang, C. C. and Lin, C. S. (2006): Seminal malondialdehyde concentration but not glutathione peroxidase activity is negatively correlated with seminal con 
centration and motility. Int J Biol Sci; 2:2329.

Jabbońska-Czapla M. (2014): Arsenic, Antimony, Chromium, and Thallium Speciation in Water and Sediment Samples with the liquid chromatography- inductively coupled plasma-mass spectrometry (LC-ICP-MS) Technique. Int. J. of Analytical Chemistry, 2015: 1-13.

Johnson C. and Radhakrishnan M.V. (2016): Histopathological Analysis of Chromium Toxicity to Testis of the Catfish Clarias batrachus (Linn.). IOSR Journal of Environmental Science, Toxicology and Food Technology (IOSR-JESTFT);10 (1): 01-04.

Khalil W K. B., Ahmed K A. , Park M H. · Yong T. $\mathrm{K} \cdot$ Hyung H. P and Abdel-Wahhab M A. (2008): The inhibitory effects of garlic and Panax ginseng extract standardized with ginsenoside $\operatorname{Rg} 3$ on the genotoxicity, biochemical, and histological changes induced by ethylenediaminetetraacetic acid in male rats. Arch Toxicol (2008) 82:183195. DOI 10.1007/s00204-007-0237.

Kim S.H., Lee I.C., Baek H.S. and Moon C. (2012): Pycnogenol® prevents hexavalent chromium-induced spermatotoxicity in rats. Mol Cell Toxicol 8:249-256.

MacFarquhar J.K., Broussard D.L., Melstrom P., Hutchinson R., Wolkin A., Martin C., Burk R.F., Dunn J.R., Green A.L., Hammond R., Schaffner W. and Jones T.F. (2010): Acute selenium toxicity associated with a dietary supplement. Arch. Intern. Med., 170: 256261.

Marouani N, Tebouri O, Hallegue D, Mokni M, Yacoubi MT, Sakly M, Benkhalifa M and Rhouma KB (2017): Mechanisms of chromium hexavalent-induced apoptosis in rat testes. Toxicol Ind Health 33:97-106

Mohammad M. (2017): Medicinal Herbs, Strong Source of Antioxidant in Aquaculture: A Mini Review. Mod Appl Pharm Pharmacol.; 1(1): $1-5$

Myers JM, Antholine WE and Myers CR (2011): The intracellular redox stress caused by hexavalent chromium is selective for proteins that have key roles in cell survival and thiol redox control. Toxicology 281:3747

Nassar SA, Zayed FA, Hegab FA, Mossaad MN and Harfoush AS. (2012): Cytogenetic, histological and histochemical studies on the effect of gibberllin A3 in albino rats. Journal of American Science; 8(1):608-22.
Ognjanović B.I., Marković S.D., Pavlović S.Z., Zikić R.V., Stajn A.S. and Saicić Z.S. (2008): Effect of chronic cadmium exposure on antioxidant defense system in some tissues of rats: protective effect of selenium. Physiol. Res., 57(3): pp 403-411.

Ognjanović B.I., Marković S.D., Pavlović S.Z., Zikić R.V., Stajn A.S. and Saicić Z.S. (2008): Effect of chronic cadmium exposure on antioxidant defense system in some tissues of rats: protective effect of selenium. Physiol. Res., 57(3): pp 403-411.

Pears AGE. (1985): Histochemistry the Oretical applied volum two: Analytical technology, Churchill living stone, 4th ed. Edinburgh, London Mellowric and New York.

Rajkowski KM, Cittanova N, Desfosses B and Jayle MF. (1977): Enzyme Linked immunosorbent assay for the quantitative determination of testosterone in human serum of plasma. Steroids; 29(5):115-24.

Richmond W. (1974): Preparation and Properties of a Cholesterol Oxidase from Nocardia sp. and Its Application to the Enzymatic Assay of Total Cholesterol in Serum. Clinical Chemistry; 19(12):1350-6. Saha J., Choudhuri S. and Choudhuri D. (2017): Effect of sub chronic exposure to chromium on hematological and biochemical parameters of male albino rats. Asian J Pharm Clin Res; 10 (5): 345-348.

Saito Y., Yoshida Y., Akazawa T., Takaahashi K. and Niki E. (2003): Cell death caused by

selenium deficiency and protective effect of antioxidants. J. Biol. Chem., 278: 3942839434.

Salamone M, Heddle1, Stuart E and Katz M. (1980): Towards an improved micronucleus test: studies, on 3 model agents, mitomycin $\mathrm{C}$, cyclophosphamide and dimethyl Benz anthracene. Mutat. Res.; 74: 347-56.

Shati A.A. (2014): Ameliorative effect of vitamin E on potassium dichromate-induced hepatotoxicity in rats. J. of King Saud University - Science, 26: 181-189.

Shil K and Pal S (2017): Hexavalent chromiuminduced alteration of carbohydrate bioenergetics: a dose-dependent study. Asian J Pharm Clin Res 10:410-417

Shruthi S. and Vijayalaxmi K. (2016): Antigenotoxic effects of a polyherbal drug septilin against the genotoxicity of cyclophosphamide in mice. Toxicology reports; 3: 563-71 
Skakkebaek NE, Meyts ER, Louis GM, Toppari J, Andersson AM and Eisenberg ML (2016): Male Reproductive Disorders and Fertility Trends: Influences of Environment and Genetic Susceptibility. Physiological Reviews; 96(1):55-97.

Sun H , Brocato J , and Costa M (2015): Oral Chromium Exposure and Toxicity. Curr Environ Health Rep. 2015 Sep; 2(3): 295303. doi: 10.1007/s40572-015-0054-z

Trinder P. (1969): 24 Determination of Glucose in Blood using Glucose Oxidase with an alternative oxygen acceptor. Ann. din. Biochem.; 6: 24-7.

Uzunhisarcikli M., Kalender Y., Dirican K., Kalender S., Ogutcu A. and Buyukkomurcu F. (2007): Acute, subacute and subchronic administration of methyl parathion-induced testicular damage in male rats and protective role of vitamins $\mathrm{C}$ and $\mathrm{E}$. Pesticide biochemistry and physiology, 87: 115-122.

Valette H, Dolle F, Bottfaender M, Hinnen F and Marzin D. (2002): Fluro-A-85380 demonstrated no mutagenic properties in vivo rat micronucleus and Ames tests. Nucl. Med and Biol.; 29:849-53.

Valko M, Leibfritz D, Moncol J, Cronin MT, Mazur $\mathrm{M}$ and Telser J.(2007): Free radicals and antioxidants in normal physiological functions and human disease. Int $\mathrm{J}$ Bio chem Cell Biol 39:44-84

Vernet P, Aitken RJ and Drevet JR (2004). Antioxidant strategies in the epididymis. Mol. Cell Endocrinol. 216(1-2):31-39.

Wang JC, Gray NE, Kuo T and Harris CA (2012): Regulation of triglyceride metabolism by glucocorticoid receptor. Cell Biosci 2:1925.

Wyrobek A, watchmarkrs G and Gorden L. (1984): Sperm morphology testing in mice. In: "Hand book of mutagenicity test procedures" 2nd ed., Elsevier Science, publishers. page 739-50.

Yousif AS and Ahmed AA. (2009): Effects of cadmium $(\mathrm{Cd})$ and lead $(\mathrm{Pb})$ onthe structure and function of thyroid gland. Afr J Environ Sci Technol;3(3):78-85. 


\section{الملخص العربي}

الدور الوقائي المحتمل لفيتامين هـ والسيلينيوم ضد السمية تحت المزمنة من الكروم سداسي التكافؤ على الخصيثين فى ذكورالفئران البيضاء البالغين

\section{أميرة عبد الرعوف محمد' و وسدام عبد السلام عبد الوهابr}

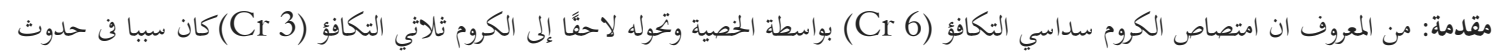

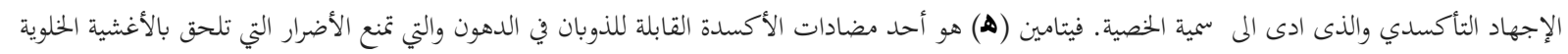
أيضا السيلينيوم هو من المغذيات الدقيقة الأساسية ذات النشاط المضاد للأكسدة. الهدف من هذه الدراسة:لذلك ، كان المدف من هذه الدراسة هو تقييم الدور الوقائي المتمل لفيتامين هو والسيلينيوم ضد السمية تحت المزمنة للكروم

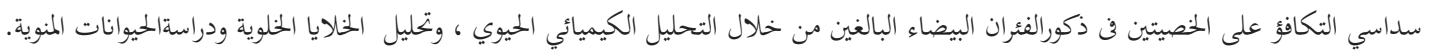

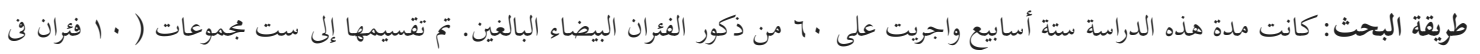

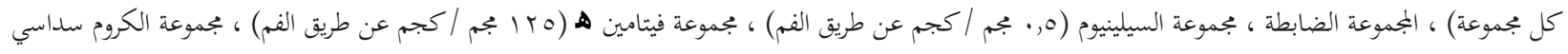

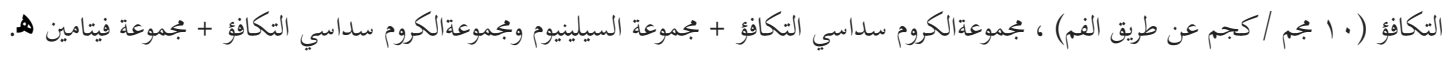

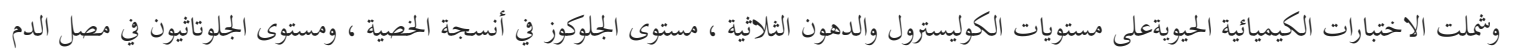

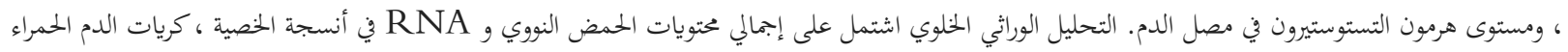

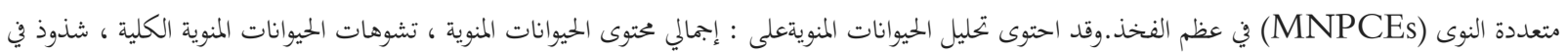

$$
\text { الرأس والذيل ونسبة صلاحية الحيوانات المنوية. }
$$

النتائج: أسفرت سمية Cr (6 تحت المزمنة عن تغيرات بيوكيميائية وخلوية وتغيرات فن الحيوانات المنوية متمثلة ف :زيادة مستويات الكوليسترول والدهون

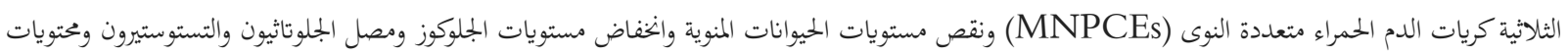

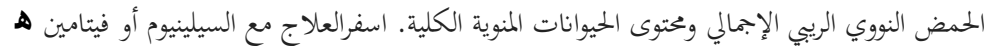
إلى ت إنسن في كل هذه الآثار.

الحلاصة: تسبب الكروم سداسي التكافؤ في احداث التغييرات فن العوامل الحيوية والكيميائية الخلوية فن خصية الفئران ، منما يؤدي إلى تعطيل وظائف الخلاياي

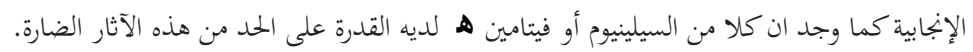

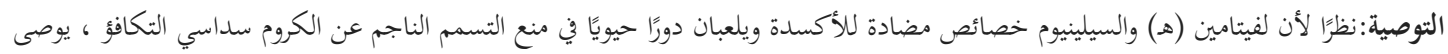

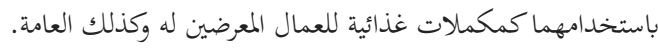

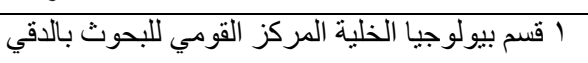
r قسم الطب الشرعى والسموم الإكلينيكية كلية الطب بنات - جامعة الأزهر 